\title{
@ RE-ART. HOW TO MIX A VIRTUAL TOUR, ARCHIVING AND A SOCIAL MEDIA STRATEGY ON THE WEB TO INVOLVE A NEW PUBLIC AND BRING AWARENESS TO THE MUSEUM AND THE EXHIBITION
}

\author{
Dalia Gallico \\ Università San Raffaele Roma, Italy
}

\begin{abstract}
The forced closure of cultural realities, dictated by the Coronavirus emergency, generated new needs for urgent solutions. Italy has heavily suffered as everything has been interrupted: exhibitions, trade fairs and museums, between more or less hard lockdowns and \#iorestoacasa. From the spread of the virus, that thanks to vaccines sooner or later will begin to wane, to the spread of beauty that will help us revive the world. This is the path to follow and Italy a generator of beauty since ancient times, will have to be at the forefront of this mission. The reason is soon to be said. The aesthetic emotion brings man closer: the first sensation we experience in front of something beautiful - whatever it is - is that of not being alone. To encourage the meeting of beauty and people, many have done their utmost, let's think for example of the campaigns \#museichiusimuseiaperti, \#laculturanonsiferma, \#MuseumFromHome, so well organized as to successfully substitute real life visits to museums and galleries, at least for the moment. Thanks to digital technology that allows activities to be carried out in places of art and culture and the distribution of content by all the main cultural institutions through social media. For the first time, the doors of the Web open wide and present to the public, through viewing rooms and virtual exhibition spaces, shows of all kinds. Broadening the horizon, the same choice is made by art galleries around the globe. Changing only the exhibition spaces, no longer physical but digital. Thanks to immersive 3D technology, one can enjoy the sensations and atmospheres of traditional visits. Therefore, the cultural mission of museums is not interrupted, rather it is strengthened and new projects are born exclusively for the Web that follow the themes of the moment. The @ Re-Art project fits into this scenario which aims to combine the dynamism of multimedia and digital means of communication (webinar, podcast, social network, virtual tour, and exhibitions intended for the Web) with the uniqueness of the carefully archived heritage from Milanese exhibitions of the past two decades. A way to make them accessible, galvanize them and bring them into circulation, making them live again.
\end{abstract}

\section{KEYWORDS}

Virtual Tour, Exhibition, Web, Social Media, Covid, Digital Archive

\section{INTRODUCTION}

The Covid-19 Emergency has had a dramatic and unprecedented impact on museums around the world. On several occasions, the drastic personnel cuts in the sector have already been written about, as well as the hypothesis of new strategies for a less "standardized" museum fruition. To better understand the effects of the pandemic on museums around the world, NEMO - Network of European Museum Organizations - launched a survey (between March $24^{\text {th }}$ and April 30 $0^{\text {th }} 2020$ ) which involved around 1.000 museums from 48 countries including Italy, the United Kingdom, France, Germany and the United States. This analysis is part of a context that is dramatic in itself given that $93 \%$ of museums around the globe have been forced to close their doors as a result of state provisions, generating losses which, compared to pre-virus volumes, range from $75 \%$ to $80 \%$ per week. If we want to translate these figures, it is around $€ 10.000$ per week for smaller museums, up to hundreds of thousands of euros for the larger ones. To be more precise, three out of five museums reported losses of around $€ 20.000$ per week. Institutions including the Rijksmuseum and the Stedelijk in Amsterdam and the Kunsthistorisches Museum in Vienna have lost between $€ 100.000$ and $€ 600.000$ per week. In any case, among these, the ones that suffered most were those museums that support themselves thanks to private financing, that are more susceptible to changes and 
unforeseen events. Museums have suffered the consequences of the tourism blockade - according to the European Commission in this sector a decrease of between $50 \%$ and $70 \%$ is estimated - and, if we consider that $40 \%$ of European tourism is cultural, the prospects for the future are not the best.

The good news is that compared to American museums, most of those in Europe did not have to lay off their employees but, three out of ten museums have suspended their contracts with freelancers, and three out of five have stopped volunteer projects. $25 \%$ of museums said they will have to reduce staff in the future. Smart working appears to have been used in a widespread way: nearly half of the museums that responded to the NEMO survey stated that $80 \%$ of their staff work from home. With Regard to the emergency funds made available by governments, the panorama is varied. Museums from 15 countries said measures to address the emergency are still under discussion while special funds have already been made available in 12 countries. This difference is due to several factors, ranging from the development in the spread of Covid-19 to the typology of museum. The aid is intended to cover wages or lost earnings. Only $15 \%$ of museums are evaluating the possibility of finding alternative resources to make up for the huge losses. Of these, $7 \%$ trust in the possibility of making money through online programming.

\section{DIGITAL SERVICES \& VIRTUAL TOURS}

Four out of five museums have upgraded their digital services to reach the public, often giving employees new tasks and duties. Nearly half of the museums that responded to the survey said they had promoted at least one new online business. $70 \%$ of the museums have increased their presence on Social Networks (see Figure 1). The platform most used by 602 museums is Facebook compared to only 183 who have chosen Instagram. Then they use YouTube, Twitter, LinkedIn and TikTok. Two out of five museums have seen an increase in online visits, between $10 \%$ to $150 \%$. Products such as podcasts and direct online learning have increased significantly and, among the most popular contents, we see those dedicated to the various museum collections, with the availability of insights and information of more or less known works.

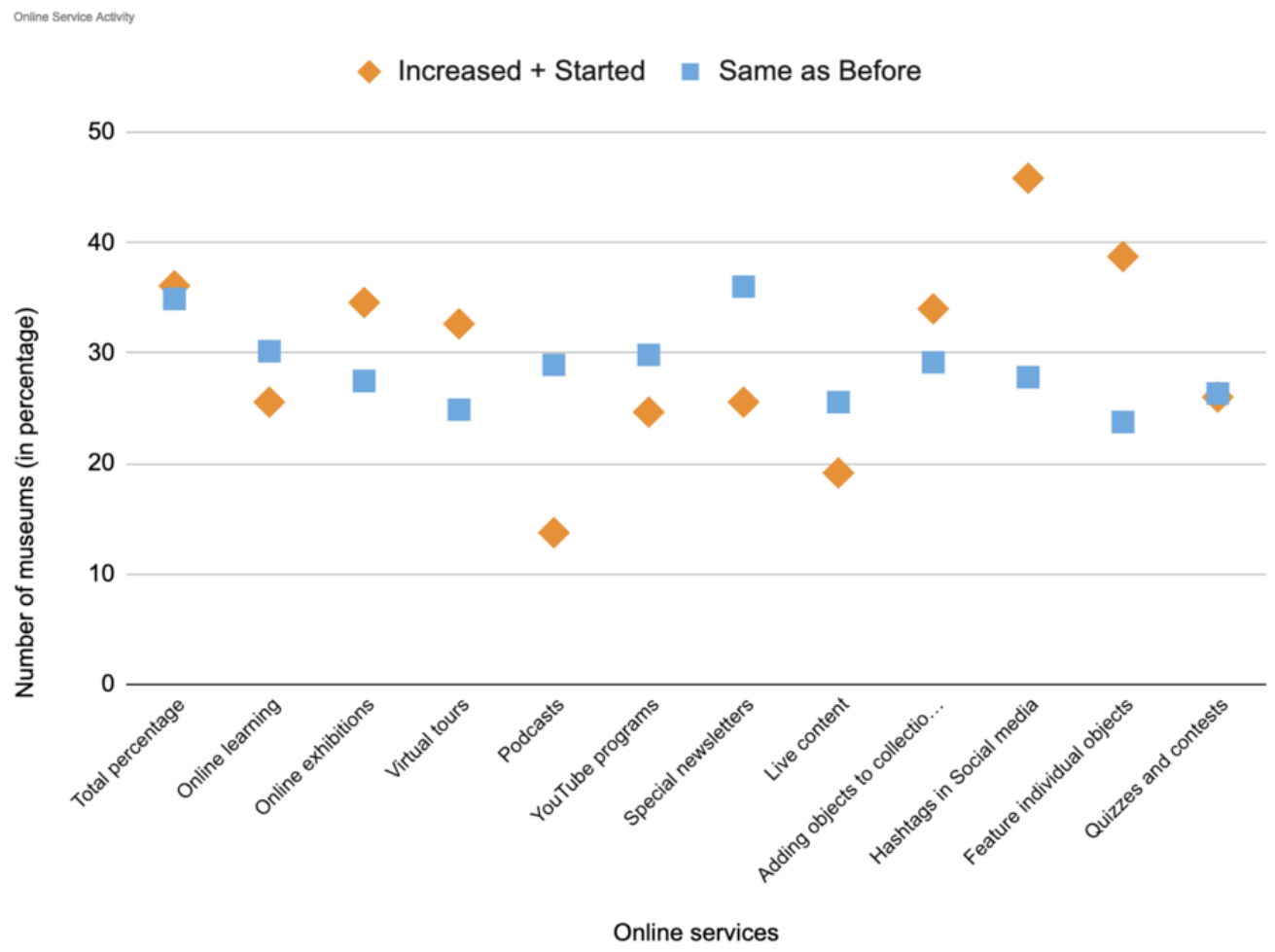

Figure 1. Increased online anctivity of museum during lockdown 
For a few days in March 2020, the world focused its attention on virtual museum tours. His attention was driven by museum closures, major media coverage, and a mighty social media effort by museums to offer an online experience to audiences. And then, just as quickly, the attention disappeared and museums were left in what might be the greatest struggle for short-term relevancy they have ever faced. The data shows that we are past peak interest in virtual museum tours. The mainstream market isn't interested in seeing these world class institutions in virtual 3D spaces or photo galleries. As the Director of the Rubin Museum of Art, Jorrit Britschgi, said: "There is nothing that can replace in-person encounters with art." However, just as interest peaked for virtual museum tours, it is now starting to peak in other areas that museums can serve. In this article, I'll share the data I mentioned and also the areas of opportunity. Google is one of the most data rich organizations ever to exist, and makes a portion of this data available to the public. Anyone can go to Google Trends, type in a query, and see search interest on Google's platform for the last 16 years. This data has several limitations, for example:

- The data is limited to Google's platform, which is popular but not quite ubiquitous. China, for example, has over 1.3 billion people that can't access Google without a VPN.

- The site does not provide number of searches and instead graphs on normalized and relative data. This structure allows for relative comparisons, without knowing whether you are analyzing in the thousands or millions.

Google provides related trends, but to a degree you still need to pinpoint an accurate search. It is possible, for example, that "online museum tours" could be a more relevant search than "virtual museum tours." It's not. Still, the data is accurate enough that we use it to make decisions on product development, marketing, staffing and other important aspects of our business. And to write blog posts. For example the results of Google's search data for "virtual museum tours" from 2019 to 2020 shows that interest in virtual museum tours started to surge on March $14^{\text {th }}$ peaked on March $17^{\text {th }}$ and has been on decline ever since. Related searches, such as "free virtual museum tours", "virtual museum tours for kids", and "online museum tours", show a similar trend. One notable exception is "best virtual museum tours" which continues to fluctuate. Data from other sources shows that the search volume with the "best" modifier is much lower than the other keywords. Some important notes:

1. With the wild fluctuations in the market, it is possible that we will see another surge in interest for virtual museum tours soon. My best guess is that for as long as the pandemic lasts, some interest in virtual museum tours will remain, but that we are still past peak.

2. This analysis is about the market size of virtual museum tours, and not otherwise a judgement of their quality or importance. For example, virtual museum tours are one way to make a museum and its collection more accessible.

\section{PROJECT @ RE ART THE OBJECTIVES}

Also in light of the fact that for some time it will not be possible to use the exhibition spaces except for very limited numbers of people, the need to produce narrative contents that rework the contents of past exhibitions and collect new ones designed for the digital. It is about collecting ideas and contents from the scientific committee to be reworked and conveyed on social networks. Alongside the strategy will be direct actions, that is writing and editing actions (written, video, audio, production of the collected contents). The aim is to increase the "followers" of the exhibitions and create a real community of enthusiasts who also actively participate with comments and ideas. The @ RE ART Multimedia platform aims to stimulate and disseminate a critical approach to the culture of the exhibition project through the 'collateral' content that is produced for exhibitions, catalogs, seminars and meetings. @ RE ART aims to broaden the territorial public ranges, lower the age of users and make the proposed contents more durable and in-depth. @ RE ART wants to present itself to young audiences through a channel that can be used interactively from anywhere, and become a place of study for young people, attractive and attentive to their requests, as well as a stimulus for the promotion and sharing of the exhibition activity which also includes a curatorial and realization dimension. With @ RE ART we want to broaden its impact outside the exhibition spaces (Palazzo Reale, Pac, Rotonda della Besana, Palazzo della Ragione) by virtually bringing people into the spaces and settings. From exhibition and traditional cultural institutions (where you can enter exhibitions with the purchase of a ticket) to ever-changing, open and welcoming international movement. The contents of the exhibitions stored in over 20 years of archive will become multimedia products hosted by a dedicated platform linked to an on and off line site. From exhibitions to conferences, from photos of installations to graphics, it will also be possible to experience the schedule of exhibitions (past, present and future) through a daily production of 
contents relating to individual initiatives. The artists, curators, fitters, graphic designers, technicians will hold webinars on their work, on the context in which they live and work, on the contents of the exhibition (past or future). The webinar will be dedicated to university and academy students, critics, young curators, visitors to Italian and international exhibitions (in English) but also to an audience of lovers of art and exhibitions. Postcasts will be made for the exhibitions (past and present), with interviews with the protagonists in order to expand the impact of the contents beyond the small number of visitors who can participate. The exhibition materials will also be translated into a language suitable for dissemination through Instagram and Facebook on the model of the "Harvard Business Review", with ad hoc daily editorial work followed by professional editors.With financing help by Fondazione Cariplo.

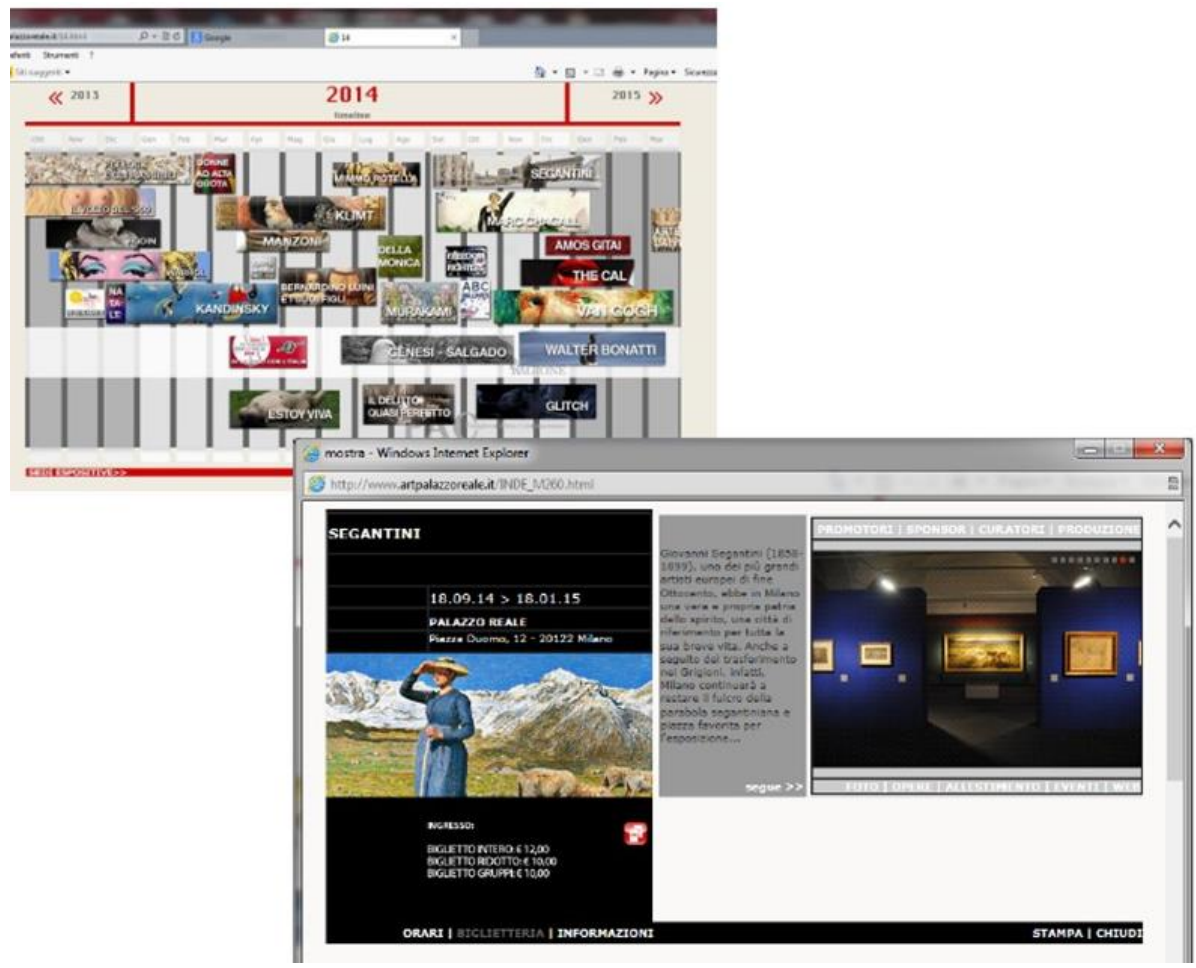

Figure 2. Timeline and details (video, photo, graphics, informations) Exhibitions in Royal Palace_Milan

\section{THE ACTIVITIES}

The activities must be articulated starting from some new rules that define contemporary communication. The first rule is that of relevance that sees a virtuous meeting between uniqueness, substance and distinction. It expresses the ability of art to emphasize passions, from the beating of hearts but also to ideas and their imagination. Artistic projects must make a difference in the everyday experience of life, with visions and messages that will be remembered and that are worth sharing in a virtual or physical space. Experiences that leave their mark allowing for the distinction of special and particular messages: Artistic UltraMessage. The second rule is that of resonance which we can consider on the other side of relevance. When you are unique and distinctive, you need to activate your So.na.r (acronym for sound navigation and ranging) intercepting the signals of widespread creativity. The phenomena are evaluated on the ability to overcome the wall of attention. For this purpose, it is interesting to understand the world of infrasound and ultrasounds perceived by dolphins and bats, which guarantees the perfect knowledge of a context through the bounce of an echo. On the web - with regard to the world of art - this will be the challenge of all-round resonance, which will go far beyond critics and industry experts.

The steps to take could therefore be:

- $\quad$ conceive and design a multimedia archiving project aimed at safeguarding and enhancing the material and intangible heritage of the exhibition; 
- $\quad$ prepare new audiovisual, graphic and multimedia materials useful for a better use of the public with information and insights related to the exhibition activity of each individual exhibition (for all types of materials produced, translation into English is provided for); for an indicative estimate, about 30/35 exhibitions per year are calculated, so about 500 exhibitions in total in 15 years;

- to contribute to the development of new public-private partnership networks that favor the establishment of the Palazzo Reale and exhibitions in order to translate information relating to their history and structure into usable content in graphic and multimedia mode;

- $\quad$ design and implementation of the material produced, recovered and processed within the audiovisual and computer equipment of an innovative teaching platform;

- $\quad$ invest on cultural amplification of contents and the blooming of inventiveness not only for the few.
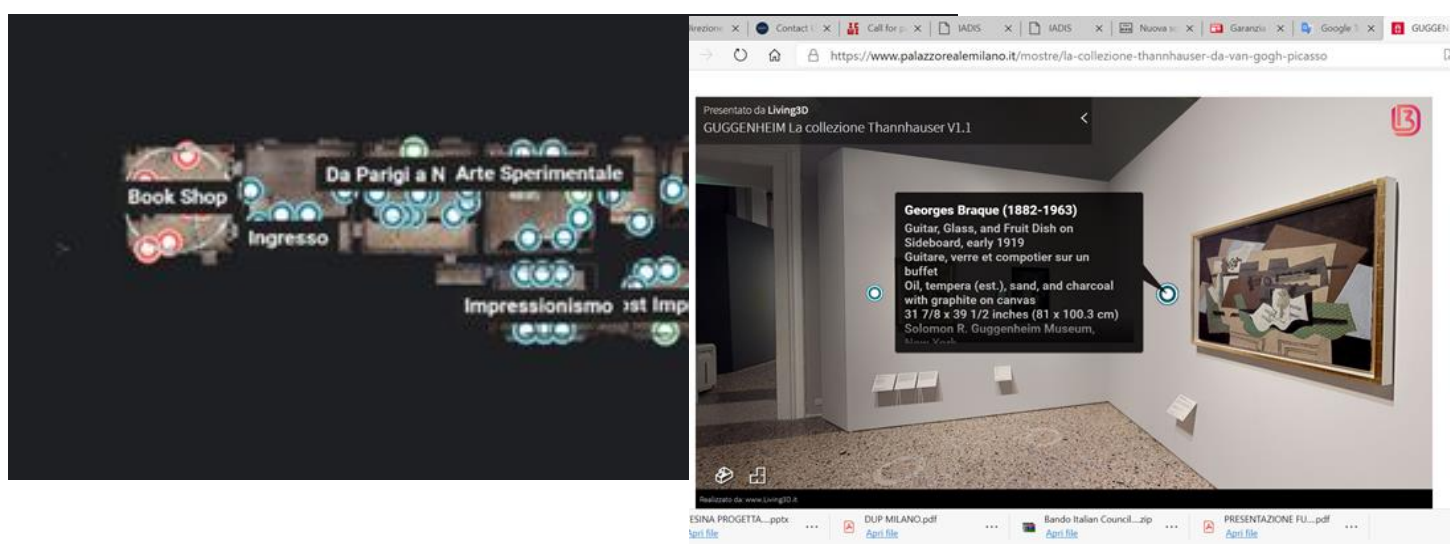

Figure 3. Virtual Exhibitions tour in Royal Palace_Milan

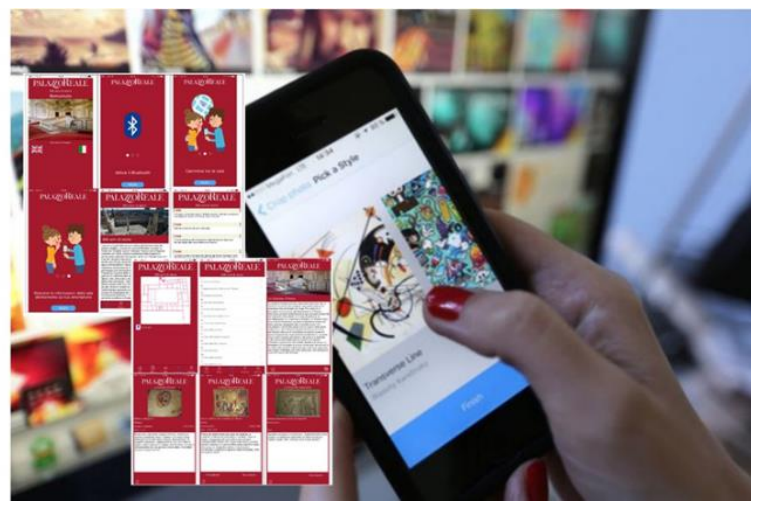

Figure 4. App Audio guide Exhibitions in Royal Palace _Milan

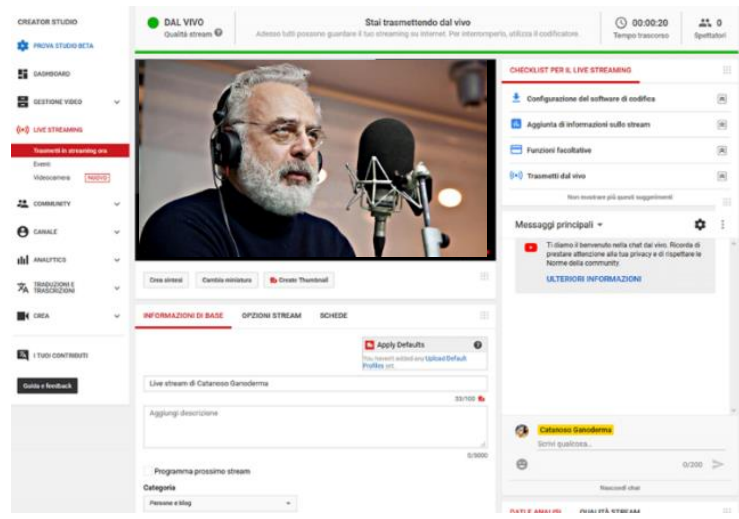

Figure 5. Live streaming curators, exhibit designers, art directors Exhibitions in Royal Palace_Milan

\section{HOW TO MIX UP VIRTUAL TOUR \& SOCIAL MEDIA STRATEGY: SOME INTERNATIONAL CASES HISTORIES}

It's easy to get caught in social media posting patterns; particularly when a majority of other museums doing the same thing. Many museums are focused on the immediate metrics following a post, i.e. how many likes and new followers. However, it's important to step back and look at overall social media strategy. Is it cohesive? It is in line with museum's mission? Look at museum's social media short-term and long-term goals alongside the strategy to determine new guidelines that help you identify alternative measures of success. 
Keep captions to a minimum as modern attention spans appreciate shorter text. The words you use to accompany an image can be a chance to tease followers. Release the title of an exhibition word by word on social media. Build up a wall of visuals to add impact to a big announcement like The Barbican in London did with their iconic brutalist architecture.

If you're feeling like audience might be tired of hearing museum's organisational voice and perspective over and over, then you're probably right. Mix things up by inviting guests to take over one of social media accounts for the day to see collection or a special event through their eyes. Today there are many cases in the world that follow the path of experimentation between art, technology, different disciplines proposing partnerships between public institutions, private companies and citizen associations. Let's view some and from each we can draw a key that will then be useful in the development of the @ RE ART project.

\section{Art \& Citizenship}

\#MuseumInstaSwap_is an initiative that was originally born in London but has now been adopted by New York City. In 2018, a whopping 42 New York City museums, galleries and arts and culture organisations participated in the now annual social media initiative aimed at highlighting the breadth of arts and culture institutions within the city. The premise is that organisations are coupled together based on their collections, interests and aims. For example, the art-deco Neue Galerie was partnered with NYC's Poster House in 2018 and the duo's posts beautifully complemented one another as there was a genuine shared interest and passion. Identify an organisation or individual with a similar ethos and social media presence and give them a shout! You may find that other museums are looking to switch up their social media as well.

Entire dissertations have been written about cat memes on the internet. The time of the meme and the GIF is now.

\section{Instant Art Occasion}

LACMA Los Angeles County Museum of Art has been a cheeky presence on social media for years with their comedic Snapchat stories and Instagram posts. They use their collection to connect with audiences and share their artworks with the world. Humour is a great way to connect with those who may find museum inaccessible either physically or mentally. Invite people to experience collection in a new way and engage digitally. Another example is the Brooklyn Museum that has a social media series featuring their staff called BKM WAY which stands for "Brooklyn Museum, We Are You". The series highlights the various departments and talented staff members behind every museum visit. Glimpsing what happens behind the scenes can help visitors to understand the bigger picture for organisation and allow them to feel more connected. Featuring staff, trustees and volunteers is something museums can do year-round, not just on the annual appreciation days. hether it be to commemorate Valentine's Day like the Royal Academy did in their cupid-inspired tweet or to take part in a new trend that's been bobbing round in newsfeed, it's important to use social media to mark special days and months.

\section{Civil Engagement \& Involvement}

Use Women's History Month (March) to highlight female artists in collection. Photography Day (19 ${ }^{\text {th }}$ August) could be used to either highlight photographs in collection, or you could explore collection through the eye of a lens. There are lots of possibilities to get creative and engage with national and international audiences. Engage followers in a social media challenge. This can be anything from an invitation for comments on a post to a full-blown curated exhibition like Seattle's Frye Museum posed to the world in 2015 for the curation of their exhibition.

\section{Single Artist Story}

If you're aiming to operate on a smaller scale, then take inspiration from the Van Gogh Museum in Amsterdam that has a dedicated Instagram story to highlighting how visitors from across the world pronounce the museum's namesake, "Van Gogh". The story puts visitors front and centre, mixing up the content from institutional voices and objects. Take some inspiration from both inside and outside museum to switch up visuals. An easy way to do this is to look a bit closer at some elements of museum's collection, architecture and/or grounds. Post some magnified images and challenge followers to identify the contents or even better, go on a scavenger hunt within museum! Chicago's Field Museum posted a magnified photo of turkey feathers around the American holiday of Thanksgiving and used the opportunity to educate visitors about the iconic birds. To change things up, look for interesting patterns, colours, textures and details within collection, then create a strategy to showcase them and engage followers in museum's collection and mission. 


\section{Artistic Tours}

With Tour [AR]T, Apple in collaboration with the New Museum in New York, is experimenting with new experiences for passionate consumers, somewhere between technological innovation and art. These are experiential tours to iconic places in cities of the United States where to discover installations by a selection of famous artists, such as Nick Cave, Nathalie Djurberg and Hans Berg, Cao Fei, John Giorno, Carsten Höller and Pipilotti Rist, made using AR. «We hope attendees are inspired... we can't wait to see what our visitors learn to create in the [AR]T Lab» affirmed Apple's Deirdre O'Brien.

\section{Art \& AI}

Los Angeles-based studio Ouchhh combines artificial intelligence with data learnt from the pre-pottery neolithic period to create DATAMONOLITH AI, a 3 billion-pixel digital monolith. Built using 6-meter-high led screens, the architectural piece of art aims to breathe new life into the world's oldest and most ancient origins. Dating back to $9600-7000$ b.C., it displays visuals produced by machine learning, which surveys data from Göbekli Tepe, an archaeological site in the southeastern Anatolia region of Turkey. It takes images collected from the site and translates them into data sculptures in the form of graphic visuals that illuminate the otherwise dark obelisk. Ferdi Alici, founder and Director of Ouchhh, explains "Our main question is: what would happen if the consciousness of the world's oldest ancient origins data and AI come together for hybrid architectural public art?" The piece is on display as part of the "Future and the Arts: AI, Robotics, Cities, Life - How Humanity Will Live Tomorrow" exhibition at the Mori Art Museum in Tokyo.

\section{Music \& AI}

In her personal research, Bjork the Icelandic artist has never neglected to take care of a positive interaction with technology. Kórsafn is an installation inside the Sister City hotel in New York that combines her creativity in the musical field with artificial intelligence, through a Microsoft program. Referring to the Icelandic word Kórsafn, made up of "kór" = "choral" and "safn" = "archives", some of her choral arrangements that she's created over the course of her 17 year career are combined using technology to give value to the Icelandic choral culture. The algorithms of the program generate exciting musical variations in real time with the passage of birds, clouds, planes and pressure changes which envelop visitors, who can listen in the lobby or online.

\section{Public Installation}

Portuguese designer Vanessa Barragão uses ecological weaving techniques to make collections of modern rugs and tapestries, using industry-wasted yarns. Lately she has created a huge map, the Botanical Tapestry installation: a large tapestry, which resembles a textile sculpture, and represents the world with references to the flora of the various continents precisely to make the public aware of pollution and the increase in water temperature. The work, commissioned from London Heathrow airport and the Royal Botanic Gardens at Kew, was positioned in the area destined for departures at London Heathrow airport, where during the month of August a large number of travellers were able to admire it. To complete the tapestry, 20 meters long, Vanessa Barragão needed 520 hours of work.

\section{Art \& Science}

With the exhibition Power Pixels 2020, taking place at the Wood Street Galleries in Pittsburgh until April $5^{\text {th }} 2020$, the french artist Miguel Chevalier (a pioneer of digital art) interprets abstract and complex phenomena in a unique and personal way, creating amazing experiences, between art and science. Of the two installations in virtual reality proposed, Complex Meshes allows the spectator to view the scientific concepts of flow and networks, intrinsically difficult to perceive, giving them form and consistency. The work is an interactive projection in which everything branches out, it intertwines and transforms according to how the spectators move in the hall.

\section{CONCLUSION}

In the new era of onlife that we live, @ RE ART is the art of remembering and telling with an innovative storytelling, aimed at creating and developing a network of information, relationships and knowledge to support the use of the exhibition activity. The peculiarity and its innovative character reside in the "transversal" approach to art, and in the activation of new communication tools to create a network of ideas 
and connections that cross the whole "system" between the public with the activities and exhibition venues connected to it. The platform will be attractive and interactive, motivating projects, areas of interest and broad surveys, creating different levels of accessibility and "narration" of the exhibition heritage, through the use of the most advanced multimedia and communication technologies. Objective: to memorize, reorganize and rationalize the information contents of the exhibitions, placing them within a path that contextualizes the temporary information (the exhibition, the layout, the graphics ...) with their cultural background (the author, the curator, the works, his history). The system will be able to manage different types of output. This means that all information can be published in the formats and through the most appropriate communication channels on the platform (such as archives or live streaming). The platform does not only want to document but to memorize, promote, communicate the exhibition reality in its daily development. We do not contemplate, we interact. The contents designed, archived and produced will become usable multimedia products hosted by a very technologically innovative platform, welcoming to a large and dedicated number of visitors. Past and future exhibitions will always be possible to experience and visit them through interviews, installations, videos, graphics, photos, virtual tours. Through a daily production of content relating to individual initiatives - to make it possible to carry out thematic researches and routes and virtual realities in the Archive of the unique exhibition heritage (set-ups, graphics, videos... etc.) of the most important exhibitions of the last twenty years. On the horizon that awaits us, some essential values clearly emerge: respect and responsibility that also in artistic and museum production imply a new management ethic. The artistic vision of those who produce works and then communicate them must take charge of a system of values, presenting, supporting and implementing their idea of quality of life, indicating the sense of experience. The new paradigms of sustainability, of personal dignity, relational empathy must be considered, as renewed playing fields on which to produce credible creative design. Relevance - the primary source of communication and resonance - must measure itself against the yardstick of respect and responsibility. Engagement then constitutes the keystone in the authentic relationship with visitors and their community, allowing the equal exchange of opinions and experiences that can and must consolidate the open discussion with one's interlocutors. The circle closes with recognition, which implies - only at the end of the process - a permanent mirroring in the observer, with interlocutors who become daily partners and who must be known and re-known, based on a common vision, a memorable message, a correct tone of voice and an ability to listen beyond the normal. The communication strategies of a museum thus enter a new dimension in which nothing is enough and everything is necessary.

\section{REFERENCES}

\#SocialMedium https://fryemuseum.org/exhibition/5631/

@ RE ART http://www.artpalazzoreale.it/

Barbican https://www.barbican.org.uk/

Field Museum https://www.fieldmuseum.org/

Floridi, L., 2020. Pensare l'infosfera. La filosofia come design concettuale. Raffaello Cortina Editore, Milano.

Floridi, L., 2017. La quarta rivoluzione. Come l'infosfera sta trasformando il mondo. Raffaello Cortina Editore, Milano.

Kórsafn Björk https://www.microsoft.com/inculture/musicxtech/bjork/

LACMA Los Angeles County Museum of Art https://www.lacma.org/

Mandarano, N., 2019. Musei e media digitali. Carocci Editore, Roma.

Morace, F. , 2018. Futuro più umano. Quello che l'intelligenza artificiale non potrà mai darci. Egea, Milano.

Mori Museum Tokyo https://ouchhh.tv/AI-DATAMONOLITH-1

MuseumInstaSwap https://www.museuminstaswap.org/

NEMO Network of European Museum Organizations https://www.ne-mo.org/news/article/nemo/nemo-surveyonmuseums-and-covid-19-increasing-online-activities-of-museums.html

New Museum https://www.newmuseum.org/pages/view/ar-t

Vanessa Barragão https://www.vanessabarragao.com/html/ArtworkProjects/artworkP_Botanical.html

Wood Street Galleries http://woodstreetgalleries.org/portfolio-view/miguel-chevalier/ 